\title{
Methylobacterium nodulans sp. nov., for a group of aerobic, facultatively methylotrophic, legume root-nodule-forming and nitrogen-fixing bacteria
}

\author{
Philippe Jourand, ${ }^{1}$ Eric Giraud, ${ }^{1}$ Gilles Béna, ${ }^{1}$ Abdoulaye Sy, ${ }^{1}$ \\ Anne Willems, ${ }^{2}$ Monique Gillis, ${ }^{2}$ Bernard Dreyfus ${ }^{1}$ and Philippe de Lajudie ${ }^{1}$ \\ 'Laboratoire des Symbioses Tropicales et Méditerranéennes, UMR 1063, IRD/CIRAD/INRA/ \\ Agro-M/UMII, TA 10/J, Campus International de Baillarguet, 34398 Montpellier cedex 5, \\ France \\ ${ }^{2}$ Laboratory of Microbiology, University of Gent, Ledeganckstraat 35, 9000 Gent, Belgium
}

Correspondence

Philippe Jourand

jourand@mpl.ird.fr
The genus Methylobacterium includes a variety of pinkpigmented facultatively methylotrophic (PPFM) bacteria that are able to grow on $\mathrm{C}_{1}$ compounds such as formate, formaldehyde and methanol as sole carbon and energy sources as well as on a wide range of multi-carbon growth substrates (Green, 1992). At the time of writing, the genus Methylobacterium consists of 14 PPFM species (Doronina et al., 2002), with Methylobacterium organophilum as the type species (Patt et al., 1976). Methylobacterium strains have been found on many plant tissues but no symbiotic association with plants has been reported (Holland, 1997). Recently and surprisingly, 16S rRNA gene-based phylogenetic analysis classified non-pigmented bacteria isolated from legume root nodules of three Crotalaria species (subfamily Papilionoideae, tribe Crotalarieae), i.e. Crotalaria glaucoides, Crotalaria perrottetii and Crotalaria podocarpa, in the genus Methylobacterium (Sy et al., 2001a, b). More

Published online ahead of print on 1 July 2004 as DOI 10.1099/ ijs.0.02902-0.

The GenBank/EMBL/DDBJ accession numbers for the 16S rRNA and partial nifH gene sequences of strain ORS $2060^{\top}$ are AF220763 and AJ512205, respectively. recently, other nitrogen-fixing isolates from root nodules of the legume Lotononis bainesii (Papilionoideae, Crotalarieae) were characterized as pigmented methylotrophic bacteria (Jaftha et al., 2002). Here we review previous reports on Methylobacterium strains that nodulate Crotalaria species and add additional phenotypic and genotypic characterization data, such as morphology, physiology, enzymic and carbon sources assimilation tests, antibiotic resistance and nifH gene sequence, and conclude with the proposal of Methylobacterium nodulans sp. nov.

A group of 72 bacterial strains was isolated from root nodules samples from three Crotalaria species (C. glaucoides, C. perrottetii and C. podocarpa) sampled in five different geographical areas of Senegal (West Africa) (Samba et al., 1999). SDS-PAGE protein pattern analysis clearly indicated that these strains constituted a homogeneous group that was separate from other known legume-noduleforming bacteria (Samba et al., 1999; Sy et al., 2001a). Eleven strains, representative of the different SDS-PAGE subclusters and for plant and geographical origins, were chosen and studied further. The 16S rRNA PCR-RFLP profile analysis on these strains confirmed the homogeneity of this group 
and the 16S rRNA gene sequence analysis of two of them, ORS $2060^{\mathrm{T}}$ and ORS 1924 presenting $100 \%$ identity, showed their close phylogenetic relationship with members of the genus Methylobacterium (Sy et al., 2001a, b). The methylotrophic metabolism of the same 11 strains was confirmed by growth on MMS medium (Green, 1992) with $\mathrm{C}_{1}$ compounds as sole carbon source: methanol, formate and formaldehyde but not methylamine (Dreyfus et al., 1999; Sy et al., 2001b). In addition, an mxaF gene, encoding the methanol dehydrogenase required for methanol utilization, was detected by PCR in the 11 strains and the mxaF gene sequence of ORS $2060^{\mathrm{T}}$ showed $88 \%$ identity to that of M. organophilum (Sy et al., 2001b). Taken together, these data confirmed that the bacterial strains isolated from root nodules of C. glaucoides, C. perrottetii and C. podocarpa constituted a homogeneous bacterial group that belonged to the genus Methylobacterium.

Cross-inoculation and nitrogen fixation tests on legume plants revealed both nodulation specificity and nitrogenfixing efficiency within the genus Crotalaria (Sy et al., 2001a). Representative strains for the main Methylobacterium species, i.e. Methylobacterium extorquens, Methylobacterium organophilum, Methylobacterium radiotolerans, Methylobacterium rhodinum, Methylobacterium mesophilicum, Methylobacterium rhodesianum and Methylobacterium zatmanii, and two Methylobacterium spp. were tested for plant nodulation but none of them was able to induce any legume root nodule (Sy et al., 2001b). In addition, the nodA gene, present in all legume-nodule-forming bacteria and encoding a key enzyme in Nod factor biosynthesis that induces legume nodulation (Martinez Romero, 1994; van Rhijn \& Vanderleyden, 1995), was detected by PCR in the strains of the novel Methylobacterium species isolated from $C$. glaucoides, C. perrottetii and C. podocarpa. In contrast, nodA was not detected in any of the main representative strains of the genus Methylobacterium mentioned above (Sy et al., 2001b). A comparative analysis of the NodA protein deduced from the nodA gene sequence showed a range of $53.1 \%$ similarity with the NodA protein sequence from Azorhizobium caulinodans to $74 \cdot 1 \%$ similarity with that of Bradyrhizobium elkanii (Sy et al., 2001b).

As a consequence of the above-mentioned results, Sy et al. (2001b) concluded that the group of strains made up of facultatively methylotrophic, root-nodule-forming and nitrogen-fixing bacteria may be regarded as a novel Methylobacterium species. In this report, we formally propose the name Methylobacterium nodulans sp. nov. to include these strains, with ORS $2060^{\mathrm{T}}$ as the type strain.

Since the report of Sy et al. (2001b), novel Methylobacterium species have been described (Doronina et al., 2002). Fig. 1 shows a $16 \mathrm{~S}$ rRNA gene-based phylogenetic tree that includes M. nodulans ORS $2060^{\mathrm{T}}$, representative strains of Methylobacterium sp. isolated from L. bainesii (Jaftha et al., 2002), 13 of the 14 validly published Methylobacterium species (the sequence of Methylobacterium aminovorans is not available) and their nearest phylogenetic neighbours. All
Methylobacterium species and strains form a separate branch, consisting of three sub-branches. One sub-branch consists of M. nodulans ORS $2060^{\mathrm{T}}$ and Methylobacterium sp. (isolated from L. bainesii) strains xct10, xct14 and xct17. M. nodulans ORS $2060^{\mathrm{T}}$ shows sequence identity values of $95 \cdot 8-97 \cdot 6 \%$ with Methylobacterium sp. strains isolated from L. bainesii (Jaftha et al., 2002), and less than $95 \cdot 2 \%$ sequence identity with the other Methylobacterium species. These similarity values confirm that $M$. nodulans constitutes a separate species in the genus Methylobacterium and that it is distinct from Methylobacterium sp. strains isolated from L. bainesii.

A partial nifH fragment (426 bp) was amplified from M. nodulans ORS $2060^{\mathrm{T}}$, as described by Jaftha et al. (2002), and sequenced (GenBank/EMBL/DDBJ accession no. AJ512205). Fig. 2 depicts a nifH-based phylogenetic tree showing the relationships of the nifH sequences of Crotalaria-nodulating strains with those of related nitrogen-fixing bacteria. A maximum-likelihood method was applied for the reconstruction of the phylogenetic tree based on inferred amino acid sequences, excluding third codon positions from the alignment (due to the saturation of this position). The phylogeny shows a close relationship among M. nodulans ORS $2060^{\mathrm{T}}$, Methylobacterium sp. isolated from L. bainesii and the nifH gene sequence from Gluconacetobacter diazotrophicus, a sugarcane endophyte of the $\alpha$ Proteobacteria. Jaftha et al. (2002) suggested the closest relationship between their Methylobacterium sp. nifH sequence was with Azospirillum brasilense. However, they did not include the G. diazotrophicus sequence in their analysis and applied a phenetic method, including all nucleotide positions in their phylogenetic reconstruction, which is thus much more sensitive to homoplasy and false reconstruction than our maximum-likelihood approach that excluded saturated positions. To the best of our knowledge, nitrogen fixation and the presence of the nifH gene have never been reported in any other species belonging to the genus Methylobacterium.

Metabolic tests were performed on the 11 strains studied previously (Samba et al., 1999; Sy et al., 2001b): ORS 2026, ORS 2045 and ORS 2076 isolated from C. glaucoides; ORS 1917, ORS 1991 and ORS $2060^{\mathrm{T}}$ isolated from C. podocarpa; and ORS 1924, ORS 1928, ORS 1937, ORS 2030 and ORS 2092 isolated from C. perrottetii. The following substrates were readily used as sole source of carbon in MMS medium at $30^{\circ} \mathrm{C}$ (Green, 1992): succinate, citrate, pyruvate, glutamate and ethanol. In addition, bacterial enzymic activities were determined using the API 20NE galleries according to the manufacturer's protocol (bioMérieux); tests for nitrate reductase and urease were positive; tests for $\beta$-galactosidase, $\beta$-glucosidase, protease, indole production and glucose fermentation were negative. API Biotype 100 galleries (bioMérieux) were also used to check assimilation and growth on 100 carbon sources as according to Kersters et al. (1984). $M$. nodulans strains were able to grow on the following substrates as sole carbon sources: (+)-D-galactose, 


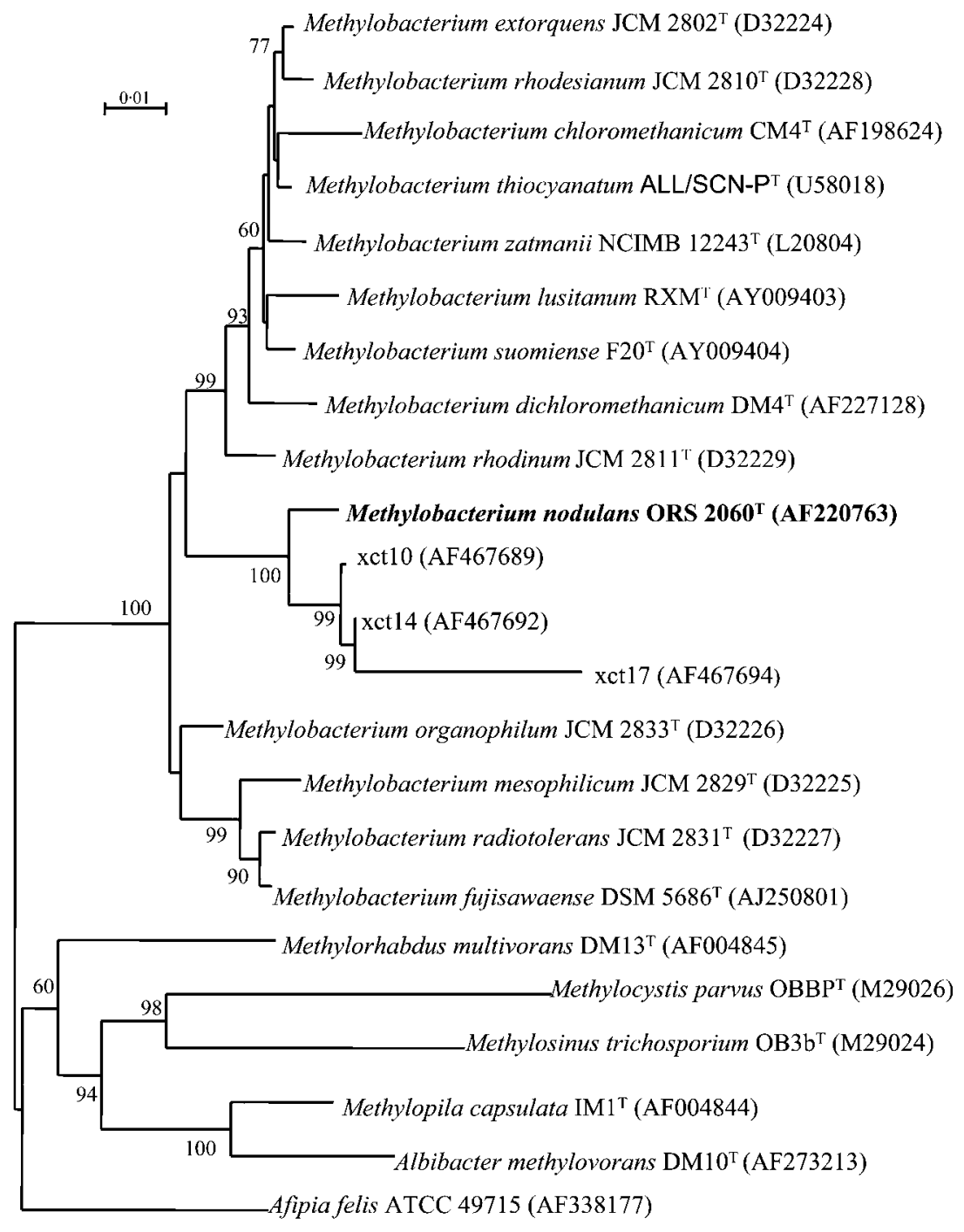

Fig. 1. Phylogenetic analysis of the $16 \mathrm{~S}$ rRNA gene sequences of strains of $M$. nodulans sp. nov. and other representatives of the genus Methylobacterium and related genera. The 16S rRNA gene was PCRamplified from pure DNA of strain ORS $2060^{\top}$ and sequenced using primers as described by Sy et al. (2001b) and an ABI Prism BigDye terminator cycle sequence kit (Applied Biosystems). The sequence was analysed on an Applied Biosystems model 310 DNA sequencer and its software, Sequence Navigator. Other 16S rRNA gene sequences from representative Methylobacterium species and related genera were from the GenBank database (accession numbers are given in parentheses). All sequences were aligned using the Multalign software (Corpet, 1988). The tree was generated using the neighbour-joining method of Saitou \& Nei (1987) and CLUSTAL_X software (Thompson et al., 1997). Bootstraps values (100 replicates) are shown at branch points. Bar, 1 estimated substitution per 100 nucleotide positions.
$(-)$-D-ribose, $(+)$-L-arabinose, $(+)$-D-xylose, glycerol, Dlyxose, D-saccharate, mucate, $(+)$-L- and $(-)$-D-tartrate, $(+)$-D- and (-)-L-malate, cis- and trans-aconitate, tricarballylate, glucuronate, 2- and 5-keto-D-gluconate, D-gluconate, phenylacetate, $p$-hydroxybenzoate, quinate, benzoate, betaine, $\alpha$-DL-amino-n-butyrate, DL-lactate, fumarate, glutarate, DL-glycerate, $\beta$-DL-hydroxybutyrate, L-aspartate, L-proline, L-alanine, L-serine and 2-oxoglutarate. Strains were unable to use $\alpha-(+)$-D-glucose, $\beta$ - $(+)$-D-fructose, $(+)$-D-trehalose, $(+)$-D-mannose, $(+)$-L-sorbose, $\alpha-(+)$ D-melibiose, sucrose, $\alpha$-lactose, $(+)$-D-raffinose, maltotriose, maltose, lactulose, $(+)$-D-cellobiose, $\beta$-gentobiose, aesculin, $\alpha$-L-rhamnose, $\alpha$ - $(-)$-L-fucose, $(+)$-D-arabitol, xylitol, dulcitol, myo-inositol, D-mannitol, D-sorbitol, tryptophan, $\mathrm{N}$-acetylglucosamine, coumarate, trigonelline, putrescine, histamine, L-histidine, ethanolamine, tryptamine, D-glucosamine, D-alanine, malonate, propionate and L-tyrosine. The intrinsic antibiotic resistance patterns of the strains show fairly high resistance to ampicillin, carbenicillin and nalidixic acid but sensitivity to kanamycin, gentamicin and tetracycline. Table 1 summarizes features useful for distinguishing M. nodulans sp. nov. from the 14 recognized species of the genus Methylobacterium (Green, 1992; Doronina et al., 2002).

\section{Description of Methylobacterium nodulans sp. nov.}

Methylobacterium nodulans (no'du.lans. N.L. v. nodulare to nodulate; N.L. part. adj. nodulans nodulating, expressing the original feature of strains to induce nitrogen-fixing nodules on roots of legume plants).

Short asporogenous Gram-negative rods $(0 \cdot 8-1 \cdot 0 \times$ $1 \cdot 0-1 \cdot 5 \mu \mathrm{m})$ that occur singly or occasionally in pairs; some are motile with one or more polar flagella. Colonies on MMS medium + agar (Green, 1992) with methanol as sole carbon source are shiny, smooth, raised, entire and $0 \cdot 5-1 \mathrm{~mm}$ in diameter after 3 days at $30{ }^{\circ} \mathrm{C}$ and are not pigmented. Optimal growth occurs at $\mathrm{pH} 6 \cdot 8-7 \cdot 5$ and at $30-37^{\circ} \mathrm{C}$. Strictly aerobic, catalase-positive and weakly oxidase-positive; urease-positive and able to reduce nitrate into nitrite. Table 1 shows other phenotypic traits of the 


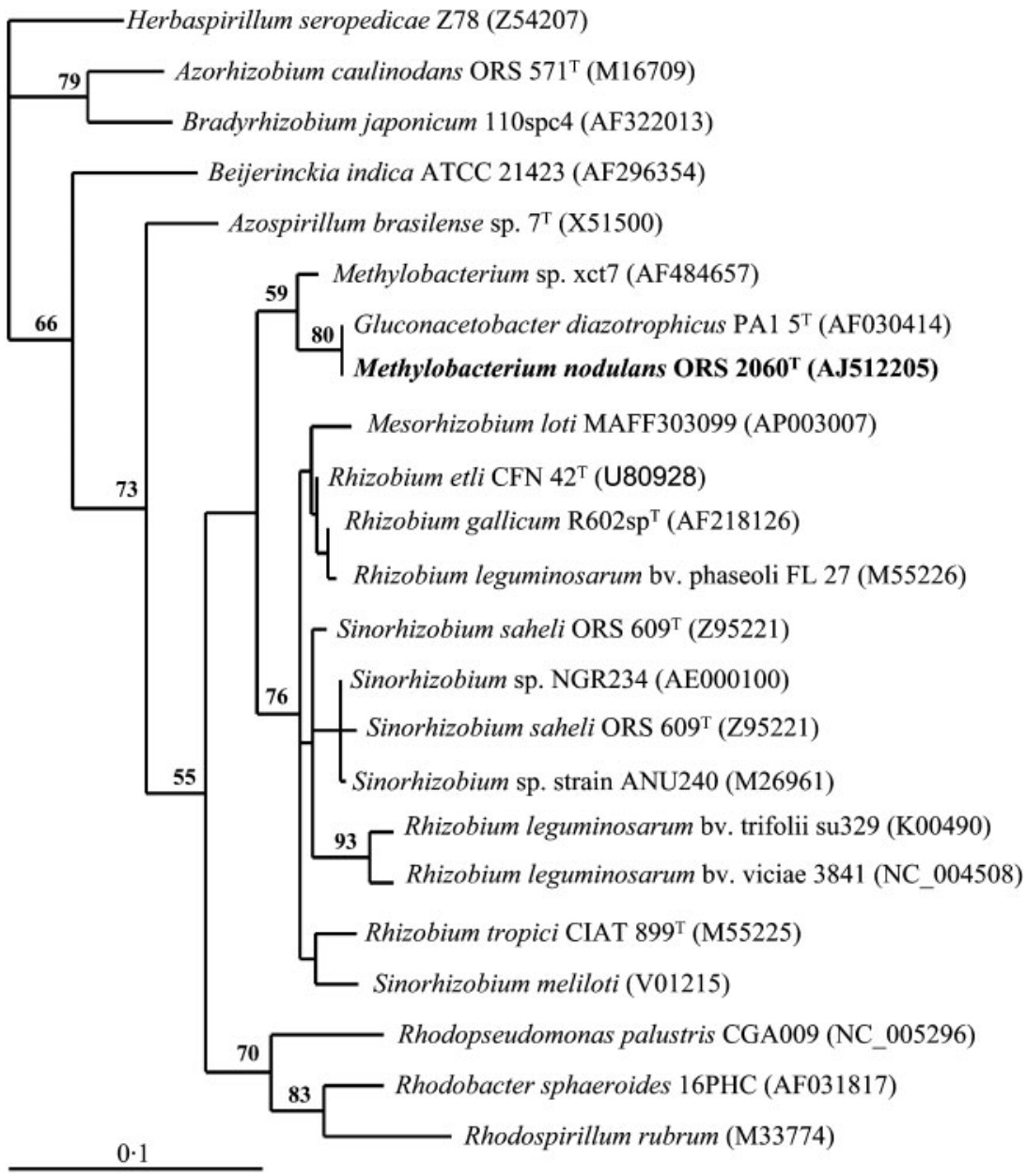

Fig. 2. Phylogenetic tree based on a $426 \mathrm{bp}$ fragment of the nifH gene, showing relationships of $M$. nodulans ORS $2060^{\top}$ with other nitrogen-fixing bacteria of the $\alpha$ - and $\beta$-Proteobacteria. nifH was PCRamplified using primers as described by Jaftha et al. (2002) and sequenced as described in Fig. 1. nifH sequences from representative species of nitrogen-fixing bacteria were from the GenBank database. Sequences were multi-aligned using the CLUSTAL_X software (Thompson et al., 1997), and the phylogenetic tree was generated using PAUP* version 4.0b10 (Swofford, 1998) applying a maximum-likelihood method, estimating base frequencies, the six-parameters instantaneous rate matrix substitution, the shape of the gamma distribution used to accommodate among-site rate variation (three categories) and, finally, estimating the proportion of sites unable to accept substitutions (GTR $+\Gamma_{3}+\mathrm{l}$ model). The reconstruction is based on the first and second codon positions only. Bootstrap values are indicated in bold and were estimated from 100 replicates. GenBank/EMBL/ DDBJ accession numbers are in parentheses.

species. The GenBank/EMBL/DDBJ accession numbers for the 16S rRNA, mxaF, partial nodA and partial nifH gene sequences of strain ORS $2060^{\mathrm{T}}$ are AF220763, AF220764,
AF266748 and AJ512205, respectively. Can form nitrogenfixing root nodules in symbiosis with Crotalaria glaucoides, Crotalaria perrottetii and Crotalaria podocarpa.

Table 1. Characteristics useful for distinguishing M. nodulans sp. nov. from other species of the genus Methylobacterium

Species: 1, Methylobacterium nodulans ORS $2060^{\mathrm{T}}$; 2, M. organophilum; 3, M. extorquens; 4, M. rhodinum; 5, M. zatmanii; 6, M. mesophilicum; 7, M. rhodesianum; 8, M. fujisawaense; 9, M. radiotolerans; 10, M. aminovorans; 11, M. thiocyanatum; 12, M. chloromethanicum; 13, M. dichloromethanicum; 14, M. suomiense; 15, M. lusitanum. Tests are based on the assimilation of various compounds as sole source of carbon. Abbreviations: +, growth; -, no growth; w, weak growth; V, variable; ND, not determined.

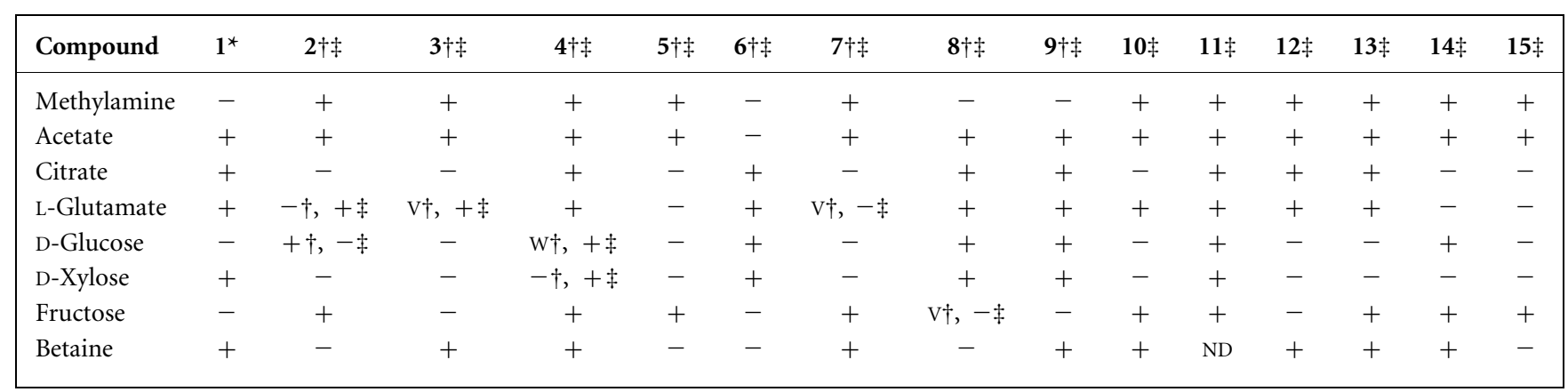

${ }^{\star}$ Results of the 11 strains studied including ORS $2060^{\mathrm{T}}$.

$\dagger$ Data from Green (1992).

¥Data from Doronina et al. (2002). 
The type strain is ORS $2060^{\mathrm{T}}\left(=\mathrm{CNCM}\right.$ I $2342^{\mathrm{T}}=\mathrm{LMG}$ $21967^{\mathrm{T}}$ ), isolated from C. podocarpa from the Bel-Air area, Dakar, Senegal. Most of the molecular and physiological studies were conducted on this strain.

\section{Note added in proof}

While this article was being reviewed, Methylobacterium populi was validly described (Van Aken et al., 2004).

\section{Acknowledgements}

A. S. is indebted to IRD for a doctoral grant. M. G. and A.W. are grateful to the Fund for Scientific Research - Flanders for research and personnel grants and for a fellowship as Postdoctoral Research Fellow, respectively. This work was supported by the French and Belgian Embassies through the Programme d'Actions intégrées franco-belge Tournesol (contracts 94085 and 03006ZJ), and by the Commission of the European Communities (STD programme, contracts TS2 0169-F and TS $3^{\star}$ CT92-0047; RT-program, contract BACDIVERS QLRT2001-02097).

\section{References}

Corpet, F. (1988). Multiple sequence alignment with hierarchical clustering. Nucleic Acids Res 16, 10881-10890.

Doronina, N. V., Trotsenko, Y. A., Kuznetsov, B. B., Tourova, T. P. \& Salkinoja-Salonen, M. S. (2002). Methylobacterium suomiense sp. nov. and Methylobacterium lusitanum sp. nov., aerobic, pinkpigmented, facultatively methylotrophic bacteria. Int J Syst Evol Microbiol 52, 773-776.

Dreyfus, B., Giraud, E. \& Boivin-Masson, C. (1999). Nouvelles bactéries symbiotiques et leurs applications. Brevet d'Invention no. 99 14179. Institut National de la Propriété Industrielle, Paris, France. (http://www.inpi.fr/brevet/pdf/COSMOS1/CFR02800/02800747A1.pdf). Patent WO 0134777-A 3, 17 May 2001, "Symbiotic bacteria and their uses".

Green, P. (1992). The genus Methylobacterium. In The Prokaryotes, 2nd edn, pp. 2342-2349. Edited by A. Balows, H. G. Trüper, M. Dworkin, W. Harder \& K.-H. Schleifer. New York: SpringerVerlag.
Holland, M. A. (1997). Methylobacterium and plants. Recent Res Dev Plant Physiol 1, 207-212.

Jaftha, J. B., Strijdom, B. W. \& Steyn, P. L. (2002). Characterization of pigmented methylotrophic bacteria which nodulate Lotononis bainesii. Syst Appl Microbiol 25, 440-449.

Kersters, K., Hinz, K. H., Hertle, H., Segers, P., Lievens, A., Siegmann, O. \& De Ley, J. (1984). Bordetella avium sp. nov., isolated from the respiratory tracts of turkeys and other birds. Int J Syst Bacteriol 34, 56-70.

Martinez Romero, E. (1994). Recent developments in Rhizobium taxonomy. Plant Soil 161, 11-20.

Patt, T. E., Cole, G. C. \& Hanson, R. S. (1976). Methylobacterium, a new genus of facultatively methylotrophic bacteria. Int $J$ Syst Bacteriol 26, 226-229.

Saitou, N. \& Nei, M. (1987). The neighbor-joining method: a new method for reconstructing phylogenetic trees. Mol Biol Evol 4, 406-425.

Samba, R. T., De Lajudie, P., Gillis, M., Neyra, M., Spencer-Barreto, M. M. \& Dreyfus, B. (1999). Diversity of rhizobia nodulating Crotalaria spp. from Senegal. Symbiosis 27, 259-268.

Swofford, D. (1998). PAUP*: phylogenetic analysis using parsimony ( ${ }^{*}$ and other methods), version 4. Sunderland, MA: Sinauer Associates.

Sy, A., Giraud, E., Samba, R., de Lajudie, P., Gillis, M. \& Dreyfus, B. (2001a). Certaines légumineuses du genre Crotalaria sont spécifiquement nodulées par une nouvelle espèce de Methylobacterium. Can J Microbiol 47, 503-508.

Sy, A., Giraud, E., Jourand, P. \& 8 other authors (2001b). Methylotrophic Methylobacterium bacteria nodulate and fix nitrogen in symbiosis with legumes. J Bacteriol 183, 214-220.

Thompson, J. D., Gibson, T. J., Plewniak, F., Jeanmougin, F. \& Higgins, D. G. (1997). The CLUSTAL_X windows interface: flexible strategies for multiple sequence alignment aided by quality analysis tools. Nucleic Acids Res 25, 4876-4882.

Van Aken, B., Peres, C. M., Lafferty Doty, S., Yoon, J. M. \& Schnoor, J. L. (2004). Methylobacterium populi sp. nov., a novel aerobic, pink-pigmented, facultatively methylotrophic, methaneutilizing bacterium isolated from poplar trees (Populus deltoides $\times$ nigra DN34). Int J Syst Evol Microbiol 54, 1191-1196.

van Rhijn, P. \& Vanderleyden, J. (1995). The Rhizobium-plant symbiosis. Microbiol Rev 59, 124-142. 